DOI: https://doi.org/10.34069/AI/2021.42.06.13

How to Cite:

Ovcharenko, R., Goncharova, O., Kondratenko, E., \& Maltseva, O. (2021). State policy in the field of innovation in Russia. Amazonia Investiga, 10(42), 141-148. https://doi.org/10.34069/AI/2021.42.06.13

\title{
State policy in the field of innovation in Russia
}

\section{Государственная политика в сфере инноваций в России}

Received: April 9, 2021

Accepted: May 23, 2021

\author{
Written by: \\ Roman Ovcharenko ${ }^{57}$ \\ https://orcid.org/0000-0002-4974-4962 \\ Olga Goncharova ${ }^{58}$ \\ https://orcid.org/0000-0003-1566-9367 \\ Evgenia Kondratenko ${ }^{59}$ \\ https://orcid.org/0000-0003-0286-5131 \\ Olga Maltseva ${ }^{60}$ \\ https://orcid.org/0000-0002-5647-0031
}

\begin{abstract}
The current stage of development of the entire world community, including Russia, is associated with the transition to the sixth technological order, the development of Industry 4.0, and the development of the digital economy. The importance of solving the problem of Russia's transition to an innovative path of development is obvious; numerous scientific publications of the last two decades have been devoted to this. However, the real results of the policy of the Russian state in the field of innovation are rather contradictory. Within the framework of this article, the evolution of state policy, its current trends and problems in the field of innovations in the Russian Federation are considered. The purpose of this study is to identify the features and prospects of the innovation policy of the Russian Federation. In this regard, the following tasks were set: to determine the place of Russia in the modern world in terms of the development of the innovation system, as well as its potential, to identify the features, strengths and weaknesses of the state policy of the Russian Federation in the field of innovation, and to determine possible directions for its adjustment in order to overcome the country's lag in the innovation field. Based on the results of the study, directions of economic development
\end{abstract}

\begin{abstract}
Аннотация
Современный этап развития всего мирового сообщества, в том числе России, связан с переходом к шестому технологическому укладу, развитием индустрии 4.0, развитием цифровой экономики. Важность решения проблемы перехода России на инновационный путь развития очевидна, этому посвящены многочисленные научные публикации последних двух десятилетий. Однако реальные результаты политики российского государства в сфере инноваций достаточно противоречивы. В рамках данной статьи рассмотрена эволюция государственной политики в сфере инноваций РФ, ее современные направления и проблемы. Целью данного исследования является выявление особенностей и перспектив инновационной политики РФ. В этой связи были поставлены следующие задачи: определить место России в современном мире по показателям развития инновационной системы, a также ее потенциал, выявить особенности, сильные и слабые стороны государственной политики РФ в сфере инноваций, определить возможные направления ее корректировки в целях преодоления отставания страны в инновационной сфере. По итогам исследования предложены направления экономического развития. Выводы,
\end{abstract}

\footnotetext{
${ }^{57}$ Doctor of Sociology, Professor, South-Russian Institute of Management of RANEPA, Rostov-on-Don, Russia

${ }^{58} \mathrm{PhD}$, Associate Professor, South-Russian Institute of Management of RANEPA, Rostov-on-Don, Russia.

${ }^{59} \mathrm{PhD}$, Associate Professor, South-Russian Institute of Management of RANEPA, Rostov-on-Don, Russia.

${ }^{60} \mathrm{PhD}$, Associate Professor, South-Russian Institute of Management of RANEPA, Rostov-on-Don, Russia.
} 
have been proposed. The conclusions obtained in the course of the study may be of interest to the scientific community studying the experience and problems of organizing and managing innovations in the countries solving the problem of keeping pace with the leaders of innovative development by mastering the advantages and possibilities of transition to a new technological order, the fourth industrial revolution and digitalization of the economy.

Keywords: innovation, the sixth technological order, digitalization, the fourth industrial revolution, innovative development, innovation policy.

\section{Introduction}

In modern conditions, an innovative development strategy is typical for all levels of the economy and management: the level of individual companies, individual industries and territories, the national economy as a whole, integration associations and economic ties of the global economy (Ignatova et al, 2014).

In recent decades, scientists, practitioners and government officials have considered the relevance and necessity of the transition of the Russian economy to an innovative path of development as the most important problem (Kudrin \& Gurvich, 2014). The presence of an innovative national system is the most important indicator of a country's development level (Aghmiunia et al, 2020). Researchers consider this problem in conjunction with the problems of the transition to the sixth technological order, the fourth industrial revolution, and the formation of the digital economy. (Kiraz et al, 2020; Shayganmehr et al, 2020; Chauhan et al, 2020).

The purpose of this study is to identify the current directions of the state policy of Russia in the innovation sphere. In this regard, the following tasks were set: to analyze the evolution of the state policy of Russia in the field of innovation; identify the reasons for the lack of effectiveness of this policy; identify possible directions for improving Russia's innovation policy taking into account domestic and foreign experience.

Within the framework of this article, of course, it is impossible to cover all the components of the problems of innovative development in Russia. It is advisable to dwell on some aspects of the state policy in the field of innovation, полученные в ходе исследования, могут быть интересны научному сообществу, изучающему опыта и проблемы организации и управления инновациями стран, решающих задачу преодоления отставания от лидеров инновационного развития за счет овладения преимуществами и возможностями перехода к новому технологическому укладу, четвертой промышленной революции и цифровизации экономики.

Ключевые слова: Инновации, шестой технологический уклад, цифровизация, четвертая промышленная революция, инновационное развитие, инновационная политика.

namely, on the possible directions of improving the state innovation policy giving it a comprehensive character. First of all, it is necessary to form a clear and unified understanding of the model of the economy which will replace the raw material model, to ensure consistency of measures of state policy in the field of innovation, which implies the coordination of measures of innovation, structural, financial, monetary, and social policy, as well as to improve the quality of training and implementation of strategic documents dedicated to the problems of innovative development in Russia.

\section{Literature Review}

In the scientific literature, there are various, often diametrically opposed, points of view regarding:

1) the reasons for Russia's growing lag behind developed countries in terms of the development of an innovative economy and ways to change the current situation. Thus, according to Akindinova et al. (2016), the future model of Russia's economic development (in the context of falling energy prices and, consequently, reducing state budget revenues) should be focused on the option of gradual development based on the advantages of a market economy and competition. First of all, according to Kudrin \& Gurvich (2014), modernization of the Russian economy requires, a radical reduction in the non-market sector of the economy, continuation of reforming the budgetary sectors of the economy, refusal to raise wages in the public sector if such an increase is not a consequence of 


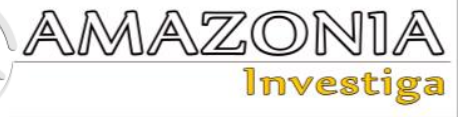

productivity growth, borrowing advanced foreign technologies and embedding, albeit in a secondary role, in international technological chains to attract foreign investment. At the same time, according to the developers of the concept of reindustrialization (Bodrunov, 2014), new industrialization (Ryazanov, 2014), neoindustrialization (Gubanov, 2014) to overcome the crisis in the innovation sphere in Russia, it is necessary, first of all, to restore the role and place of the processing industry in the economy, the connection of the extractive and processing industries on the basis of vertical integration and the creation of intersectoral chains of production of final products, as well as the elimination of threats to the reproduction of human capital;

2) regarding the transition of Russia to Industry 4.0, to the sixth technological order and the development of the digital economy in Russia. These processes are undoubtedly interrelated. The fourth industrial revolution is characterized, first of all, by the development of artificial intelligence, robotics, the Internet of things, biotechnology, 3D printing, nanotechnology, biotechnology, materials with specified properties, etc. (Bonaccorsi et al, 2020). The sixth technological order, which is currently being formed, is based on artificial intelligence, nanotechnology, genetic engineering, cellular technologies, global information networks, etc. Within the framework of the sixth technological order, there will be a significant decrease in the energy and material consumption of production (Khanzode et al, 2021). As for the development of the digital economy, it is seen as an accelerator for the development of global industry, business and society, capable, according to the World Economic Forum, to bring additional income of over $\$ 30$ trillion US dollars by 2025 (Uskov, 2018). However, for Russia, which at the end of the 20th century was unable to take advantage of the capabilities of the fifth technological order based on microelectronics, and in which the production of electronic products per capita is 90 times less than in the United States and almost 36 times less than in EU countries (Seleznev \& Sosnilo, 2016), it is necessary to clearly understand whether it is possible to create elements of a new, sixth technological order if the previous one was not developed. In addition, an unambiguous understanding of the prospects for the development of the digital economy in Russia is necessary in conditions when mechanical engineering, instrument making, electronics, and other high-tech industries form no more than 6$7 \%$ of GDP against $70-80 \%$ in the USA, Japan and developed EU countries (Goncharova \& Sidorenko, 2011). According to a number of researchers, digitalization in Russia can be effective only if the manufacturing industry is restored in the country, primarily mechanical engineering (Radulescu et al, 2014);

3) regarding the reasons for the insufficient effectiveness of the state policy of Russia in the field of innovation. As noted above, in Russia the idea of moving to an innovative track has been relevant for about two decades. During this time, many regulatory documents, concepts, strategies, road maps have been adopted; objects of innovation infrastructure have been created, etc. However, the position of our country in the world ratings of innovative development does not change dramatically. According to The Global Innovation Index 2020 (Cornell University, INSEAD, and WIPO, 2020) in the 2020 ranking compared to 2019 Russia climbed from 46th to 42nd place, according to The Global Competitiveness Report 2019 (World Economic Forum, 2019) Russia retained 43rd place in the ranking in 2019 compared to 2018 . Russia lags behind developed and many rapidly developing countries (15 leading innovative development countries and 45 EU, OECD, BRICS countries) in almost all parameters of innovation development, especially in terms of performance (Gershman et al, 2018);

4) regarding the reasons for the low demand for innovations on the part of Russian producers. An opinion is expressed about a system-forming contradiction of the current stage of development of Russia: between the course declared at the state level for the innovative development of the Russian economy and the weak demand for innovations from industrial enterprises (Romanov, 2017). According to Golichenko \& Samovoleva (2011) the low demand for innovations in Russia is associated, first of all, with the absence of market mechanisms for stimulating innovation activity; they are trying to compensate for their absence by development institutions created by the state that support innovative projects at all 
stages. According to Wang (2018) there is a relationship between the degree of government intervention in the innovation sphere and indicators of innovation development in the country's economy: government support for innovation accelerates the development of the innovation sphere, but leads to the concentration of resources at key companies. Insufficient government intervention leads, on the one hand, to lagging behind in terms of the development of the innovation sphere, but on the other hand, the innovative potential of private entrepreneurship remains.

Thus, the stated problems are very topical and controversial and directly related to the issues of ensuring the national security of the country and its existence as a sovereign state in the future. The latter presupposes the need for a radical modernization of the economic system, improvement of state policy in the field of innovation in order to meet the changes and challenges of the world socio-economic order. At the same time, it is important to coordinate efforts of state innovation policy at the federal and regional levels, which in modern conditions, as the experience of developed countries shows, is being transformed (Wilson $\&$ Souitaris, 2002).

\section{Methodology}

The research is based on a dialectical, historicalsystems approach, analysis, synthesis and comparison, induction and deduction. The study analyzed domestic and foreign literature on the topic of state innovation policy in the context of the development of Industry 4.0, the transition to the sixth technological order and the development of the digital economy. The study used data from The Global Innovation Index 2020 (Cornell University, INSEAD, and WIPO, 2020), The Global Competitiveness Report 2019 (World Economic Forum, 2019), National report on innovation in Russia 2017 (Andrushchak et al, 2018), and the Federal Service of State Statistics of Russia.

\section{Results and Discussion}

Since the 2000s, the Russian authorities have been actively adopting various regulatory legal acts, development programmes, and state development strategies in the field of innovation. For example, in 2005, a state act The Main Directions of the Policy of the Russian Federation in the Development of the
Innovation System until 2010 was adopted, in 2006 - The Strategy for the Development of Science and Innovation in the Russian Federation until 2015, in 2011 - The Strategy of Innovative Development of the Russian Federation for the Period up to 2020, in 2014 State programmes on Economic Development and Innovative Economy, on Strategy for Scientific and Technological Development of the Russian Federation for the Period up to 2024, National Project on Science (2018- 2024) and others.

Similar state acts were adopted in the field of digitalization of the economy, for example, Federal target programme on Electronic Russia (2002-2010), on Strategy for the Development of the Information Society in the Russian Federation, state programme on Information Society for 2011- 2020, on Strategy for the Development of the Russian Segment of the Information and Communication Network of the Internet and Related Sectors of the Economy, state programme on Digital Economy of the Russian Federation.

Similar strategic documents have been adopted and are being implemented in many states and within the framework of integration associations. Examples include the Digital Europe 2020 Strategy (adopted by the EU in 2010), the Internet plus Strategy (adopted in China in 2015), Industry 4.0 (adopted in Germany in 2011), etc.

However, there was no innovation boom in Russia. Let's consider the reasons.

According to a study by Patanakul \& Pinto (2014), government policies and regulations can promote or hinder innovation. Strong and focused policies and regulations have the potential to drive significant and fundamental changes in product and process technology. However, policies and regulations can create barriers and constraints that sometimes inhibit innovation. That is, in order to develop an effective state policy in the field of innovation, it is necessary to develop various government measures and test them, and those that contribute to the development of innovations should be left, but those that do not should be cancelled.

According to Greco, Locatelli \& Lisi (2017), an important factor in the development of innovation in the modern world is stimulating the development of "open innovations". "Open innovations" imply the development of new 


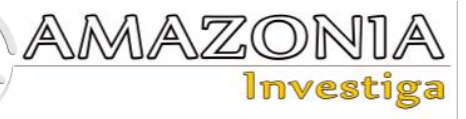

technologies, products and services not only within the framework of their own internal corporate $\mathrm{R} \& \mathrm{D}$, but also through the active involvement of innovations and competencies outside the company (Chesbrough, 2003).

Borrás \& Laatsit (2019), based on the study of state innovation policies of 28 EU countries, found that a systematic approach to innovation policy allows for the formation of a more sustainable innovation development programme but this approach requires systemic knowledge and organizational capabilities.

But it is precisely the consistency in the state innovation policy in Russia that is lacking; in addition, it has a number of significant shortcomings, namely:

- there is no analysis of the results of the implementation of previous strategies, concepts or programmes (Mindeli, 2011);

- a significant number of innovation policy priorities in the absence of a mechanism for implementing the planned measures (Chmykhalo \& Abushaeva, 2015);

- the desire to copy Western models of education, science, innovation environment, and innovation financing without taking into account domestic experience and the specifics of the Russian innovation system, which inevitably leads to temporary and financial losses, especially at the first stage (Suslov, 2011);

- unlikeliness of a number of goals set (Gershman et al, 2018);

- the vagueness of the goals and objectives of the state innovation policy (as a rule, they are formulated using the phrases like "create conditions", "create opportunities", "form a system", "promote formation", "create a model", etc.). The degree to which such goals and objectives have been achieved cannot be assessed; in this case, adjustment and analysis of the results achieved are unlikely. On the other hand, there is a real threat of loss of time and, as a result, an increase in Russia's lagging behind in the innovation sphere (Semyonov, 2019);

- little attention is paid to the integration of large innovative businesses with small and medium-sized ones. Small and mediumsized innovative entrepreneurship is an essential element of the national innovation system, ensuring its flexibility, adaptability, the possibility of cost savings, etc. Governments of developed countries are effectively expanding cooperation in the field of innovation between firms, entrepreneurs, research institutions and the public sector in such a way that small and medium-sized businesses, innovations were affordable and profitable. Whereas, big business gives small innovative companies integrated with it the opportunity to attract the necessary financial resources and reduce risks, it gives them long-term contracts, technical assistance, etc. (Leckel et al, 2020).

These problems lead to the fact that Russia shows a significant lag, its share in the global innovation system is less than $1 \%$ (Lebedeva, 2017). According to The Global Innovation Index 2020 (Cornell University, INSEAD, and WIPO, 2020), Russia climbed in the ranking in 2020 compared to 2019 from 46th to 42nd place, according to The Global Competitiveness Report 2019 (World Economic Forum, 2019) Russia retained 43rd place in the ranking in 2019 compared to 2018. Such indicators are low enough. It is necessary to state that Russia lags significantly behind developed countries in terms of funding for research and development projects. So, according to UNESCO, according to the ratio of investments to GDP, Russia is not even among the first fifteen countries (in Russia this figure is $1.12 \%$ ), whereas the average value of this indicator is $1.7 \%$ of GDP, and in the developed countries of Western Europe it is $1.75 \%$ and in North America it is $2.04 \%$ (UNESCO, 2015).

When developing measures to stimulate innovative development, the experience of other countries should be taken into account. In China, the innovation tax incentive system promotes innovation creation, diffusion and implementation. These include a reduced income tax rate for new and high-tech enterprises, deduction of $\mathrm{R} \& \mathrm{D}$ expenses for corporate income tax purposes, exemption from income tax, etc. Businesses benefit from operating in such conditions accelerating the diffusion of innovations and receiving some benefit from implementation innovation by lowering product prices (Wanga \& Lic, 2019).

In the United States, government and government agencies work effectively with startups and investors. A common way government supports startups is through direct funding, for example, the US SBIR is run through agencies (DOE and DOD) that are tasked with allocating a portion of their budget to support innovative small firms. Government organizations can also work directly with 
startups and support entrepreneurship (Doblinger et al, 2019).

In addition, the United States is actively implementing measures aimed at enhancing the capabilities of the domestic market, supporting the demand for the products of domestic producers which includes raising the standard of living of the population, reducing property differentiation, developing institutions for transforming savings into investments, etc. Market conditions are the most important factor determining the development of innovation in manufacturing (Cumming, 2007).

\section{Conclusions}

A significant part of the strategic documents of the Russian Federation (state strategies for the development of sectors of the Russian economy, the social sphere, the information economy, etc.) provide for measures to develop innovations, modernize the economy, and the social sphere. Of course, it is impossible and impractical to combine all measures to modernize, digitalize the economy, social sphere, and the civil service system in a single document. However, it is necessary to have a unified understanding of the ultimate goal of innovative transformations, to overcome the manifestations of inconsistency, internal inconsistency, disconnectiveness, state policy in the field of innovation, to ensure the possibility of taking into account different points of view, and using the domestic and world experience of implementing an innovative breakthrough in an adapted form.

At the same time, the outlined milestones should be quantitatively defined, realistic and consistent with the dynamics of development, primarily of the EAEU and BRICS countries, which, ultimately, will give an additional impetus to the development of the real sector of the Russian economy, reduce the severity of the problem of attracting investments, and ensure the participation of foreign investors in domestic infrastructure and transport projects, as well as potential sales markets for the products of the manufacturing industries of the Russian Federation.

It is equally important to study the domestic and foreign experience of overcoming the lag behind developed countries in the scientific and technical sphere, modernizing the economy, and mastering the advantages of new technological structures. This is the domestic experience of modernizing the economy and mastering the advantages of the third and fourth technological modes, the experience of China which has created its own unique and one of the most effective models of economic development in modern conditions. The period that Russia is going through is a time of opportunities including opportunities for solving the problems of overcoming the lag behind developed countries in the innovation sphere, as well as in the development of the digital economy. The future of Russia as a sovereign prosperous state which was able to realize itself and its truly enormous economic potential depends on whether in the next 10-15 years Russia will be able to master technologies and take advantage of the new technological order, while simultaneously developing those elements of the previous one the absence of which made our economy vulnerable to economic sanctions from Western countries.

\section{Bibliographic references}

Aghmiunia, S.K., Siyal, S., Wang, Q., \& Duan, Y. (2020), Assessment of factors affecting innovation policy in biotechnology. Journal of Innovation \& Knowledge, 5(3), 179189 ,

https://dialnet.unirioja.es/servlet/articulo?codigo $=7612722$

Akindinova, N., Kuzminov, Ya. \& Yasin, E. (2016). Russia's economy: Before the long transition, Economics, 6, 245-258, https://ideas.repec.org/a/nos/voprec/2016-061.html (in Russian).

Andrushchak, G.V., Artemov, S.V., Vakhshtayn, V.S. et al. (2018). National report on innovation in Russia 2017. Moscow: Russian Venture Company Publishing House (in Russian)

Bodrunov, S.D. (2014) Russian Economic System: the Future of High-tech Material Production. Economic revival of Russia, 40, 5-16 (in Russian).

Bonaccorsi, A., Chiarello, F., Fantoni, G., \& Kammering, H. (2020). Emerging technologies and industrial leadership. A Wikipedia-based strategic analysis of Industry 4.0. Expert Systems with Applications, 160, 113645, https://doi.org/10.1016/j.eswa.2020.113645

Borrás, S. \& Laatsit, M. (2019). Towards system oriented innovation policy evaluation? Evidence from EU28 member states. Research Policy, 48(1), 312-321, https://doi.org/10.1016/j.respol.2018.08.020

Chauhan, C., Singh, A., \& Luthra, S. (2020). Barriers to industry 4.0 adoption and its performance implications: An empirical investigation of emerging economy. Journal of 


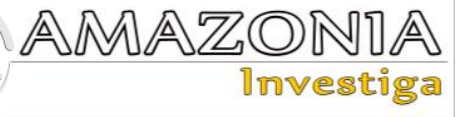

Cleaner

Production,

124809 ,

https://doi.org/10.1016/j.jclepro.2020.124809

Chesbrough, H.W. (2003). The open-innovation model. MIT Sloan Management Review, 44(3), 35-41.

Chmykhalo, A. \& Abushaeva, M. (2015). Features of the Advancement of Science as an Integral Part of the National Innovation System in Modern Russia. Procedia - Social and Behavioral Sciences, 166, 480-487, https://doi.org/10.1016/j.sbspro.2014.12.559

Cornell University, INSEAD, and WIPO (2020). The Global Innovation Index 2020: Who Will Finance Innovation? Ithaca, Fontainebleau, and Geneva.

Cumming, D. (2007). Government policy towards entrepreneurial finance: Innovation investment funds. Journal of Business Venturing, 22(2), 193-235, https://ssrn.com/abstract $=801384$

Doblinger, C., Surana, K., \& Anadon, L.D. (2019). Governments as partners: The role of alliances in U.S. cleantech startup innovation. Research Policy, 48(6), 1458-1475, https://doi.org/10.1016/j.respol.2019.02.006

Gershman, M., Gokhberg, L., Kuznetsova, T. \& Roud, V. (2018). Bridging S\&T and innovation in Russia: A historical perspective. Technological Forecasting and Social Change, 133,

132-140,

https://doi.org/10.1016/j.techfore.2018.03.014

Golichenko, O.G. \& Samovoleva, S.A. (2011). Market and government failures in the Strategy for Innovative Development of the Russian Federation until 2020. "Innovative Russia 2020". Innovations, 2, 8-10 https://cyberleninka.ru/article/n/provaly-rynka-igosudarstva-v-strategii-innovatsionnogorazvitiya-rossiyskoy-federatsii-na-period-do2020-g-innovatsionnaya-rossiya-2020 (in Russian)

Goncharova, O.Y. \& Sidorenko, I.N. (2011). Economics and bureaucracy. Rostov-on-Don, Russia: North Caucasian Academy of Public Administration Publishing House (in Russian)

Greco, M., Locatelli, G. \& Lisi, S. (2017). Open innovation in the power \& energy sector: Bringing together government policies, companies' interests, and academic essence. Energy Policy, 104, 316-324, https://doi.org/10.1016/j.enpol.2017.01.049

Gubanov, S.S. (2014). Non-industrial development model and its system algorithm. Economic and social changes: facts, trends, forecast, 33, 23-44, https://doi.org/10.15838/esc/2014.3.33.3 (in Russian).

Ignatova, T.V., Goncharova O.Y., \& Lozova, L.A. (2014). Public Innovation Management in
Entrepreneurship and Education. European Social Science Journal, 8 (1), 440-448 (in Russian).

Khanzode, A.G., Sarma, P.R.S., Mangla, S.K., \& Yuan, H. (2021). Modeling the Industry 4.0 adoption for sustainable production in Micro, Small \& Medium Enterprises. Journal of Cleaner Production, 279, 123489, https://doi.org/10.1016/j.jclepro.2020.123489

Kiraz, A., Canpolat, O., Özkurt, C., Taşkın, H. (2020). Analysis of the factors affecting the Industry 4.0 tendency with the structural equation model and an application. Computers \& Industrial Engineering, 150, 106911, https://doi.org/10.1016/j.cie.2020.106911

Kudrin, A., \& Gurvich, E. (2014). A New Growth Model for the Russian Economy. Economics, 12, 4-36, https://doi.org/10.32609/0042-8736-2014-12-436 (in Russian).

Lebedeva, A. A. (2017). Impact of sanctions on innovation potential of Russian enterprises. Scientific Notes of Young Researchers, 1, 5-11, https://cyberleninka.ru/article/n/vliyaniesanktsiy-na-innovatsionnyy-potentsialrossiyskih-predpriyatiy (in Russian).

Leckel, A., Veilleux, S. \& Dana, L.P. (2020). Local Open Innovation: A means for public policy to increase collaboration for innovation in SMEs. Technological Forecasting and Social Change, 153(C), 119891, https://doi.org/10.1016/j.techfore.2019.119891 Mindeli, L.E. (2011) About the draft Strategy of Innovation Development of the Russian Federation for the period up to 2020. Innovations, 2, 5-8 (in Russian).

Misakov, V., Tsurova, L., Yandarbayeva, L., Tkhamadokova, I., \& Gapurovna, G. (2019). Certification of a regional economic complex as a highly effective tool for analysis and diagnostics of its development. Amazonia Investiga, 8(20), 451-458. Retrieved from https://amazoniainvestiga.info/index.php/amazo nia/article/view/174

Patanakul, P. \& Pinto, J.K. (2014). Examining the roles of government policy on innovation. The Journal of High Technology Management Research, $\quad 25 \quad$ (2), 97-107, https://doi.org/10.1016/j.hitech.2014.07.003

Radulescu, I.G., Panait, M., \& Voica, C. (2014). BRICS Countries Challenge to the World Economy New Trends. Procedia Economics and Finance, 8, 605-613, https://doi.org/10.1016/S2212-5671(14)00135$\mathrm{X}$

Romanov, E.V. (2017). What capitalism does Russia need?: methodological guidelines for "new industrialization". Economic and social changes: facts, trends, forecast, 10 (2), 90-108, 
https://doi.org/10.15838/esc.2017.2.50.5 （in Russian)

Ryazanov, V.T. (2014). New Industrialization of Russia: Strategic Goals and Current Priorities. Economic revival of Russia, 40, 17-25 (in Russian).

Seleznev, P.S., \& Sosnilo, A.I. (2016). The Sixth Technological Stage and Industrialization. Power, 22(10), 14-23, https://www.jour.fnisc.ru/index.php/vlast/article /view/2720 (in Russian)

Semyonov, E.V. (2019) State Science and Technology Policy in Modern Russia: Concept and Implementation. Science Management: Theory and Practice, 1 (1), 52-71 (in Russian). Shayganmehr, M., Kumar, A., Garza-Reyes, J.A., \& Moktadir, Md.A. (2020). Industry 4.0 enablers for a cleaner production and circular economy within the context of business ethics: A study in a developing country. Journal of Cleaner Production, 125280, https://doi.org/10.1016/j.jclepro.2020.125280 Suslov, V.I. (2011). Innovative processes in Russia: a view from Siberia (ambitions and realities). Innovations, 11, 3-9. https://cyberleninka.ru/article/n/innovatsionnyeprotsessy-v-rossii-vzglyad-iz-sibiri-ambitsii-irealii (in Russian)

UNESCO (2015). UNESCO Science Report: towards 2030 - Executive Summary, http://web.nioch.nsc.ru/library/doc1/235407r.pdf (in Russian).

Uskov, V.S. (2018) Formation of digital economy in Russia in conditions of the fourth industrial revolution and new economic reality. Bulletin of The Vladimir State University. Series: Economic Sciences. 17, 182-197, http://vestnik-

es.vlsu.ru/fileadmin/No17/Vestnik_No_17.pdf (in Russian)

Wang, J. (2018). Innovation and government intervention: A comparison of Singapore and Hong Kong. Research Policy, 47 (2), 399-412, https://doi.org/10.1016/j.respol.2017.12.008

Wanga, P. \& Lic, F. (2019). China's organization and governance of innovation - A policy foresight perspective. Technological Forecasting \& Social Change, 146 (C), 304-319.

https://doi.org/10.1016/j.techfore.2019.05.029

Wilson, D. \& Souitaris, V. (2002). Do Germany's federal and land governments (still) co-ordinate their innovation policies? Research Policy, 31(7), 1123-1140, https://doi.org/10.1016/S0048-7333(01)00181-0 World Economic Forum (2019). The Global Competitiveness Report 2019. Geneva, http://www3.weforum.org/docs/WEF_TheGlob alCompetitivenessReport2019.pdf 